University of Nebraska - Lincoln

DigitalCommons@University of Nebraska - Lincoln

Robert Katz Publications

Research Papers in Physics and Astronomy

December 1950

\title{
Application of X-ray Technique to the Detection of Internal Insect Infestation of Grain
}

Max Milner

Kansas Agricultural Experiment Station, Manhattan

Milford R. Lee

Kansas Agricultural Experiment Station, Manhattan

Robert Katz

University of Nebraska-Lincoln, rkatz2@unl.edu

Follow this and additional works at: https://digitalcommons.unl.edu/physicskatz

Part of the Physics Commons

Milner, Max; Lee, Milford R.; and Katz, Robert, "Application of X-ray Technique to the Detection of Internal Insect Infestation of Grain" (1950). Robert Katz Publications. 92.

https://digitalcommons.unl.edu/physicskatz/92

This Article is brought to you for free and open access by the Research Papers in Physics and Astronomy at DigitalCommons@University of Nebraska - Lincoln. It has been accepted for inclusion in Robert Katz Publications by an authorized administrator of DigitalCommons@University of Nebraska - Lincoln. 


\title{
TRAVERSING THE INTERNET FOR USEFUL INFORMATION
}

\author{
By Julie Walker ${ }^{1}$ and Kory Bierle ${ }^{2}$, \\ ${ }^{1}$ Department of Animal and Range Sciences, South Dakota State University; \\ ${ }^{2}$ Beef Producer, Midland, SD
}

In the fast pace livestock industry producers are looking for information that can give them an edge in a timely manner. Never before has so much information been at our fingertips. The Internet is an excellent tool that can be used for obtaining good researchbased information. The type of information available on the Internet is endless. Daily, weekly and yearly reports such as market reports can be found on free sites as well as private sites. When questions arise the Internet can be a resource finder. In addition, e-mail allows you to communication with individuals on your time schedule.

Obtaining information on the Internet can be difficult, until you develop some understanding of how it works. When using the Internet, first you must decide are you looking for general information or specific topic. Three ways of getting information in general are 1) go to nearest land grant university site, 2) that favorite commodity group home page or 3) search the Internet.

To find an information site on the Internet you need a piece of software called a browser. The most common browser software packages are Netscape and Internet Explorer. Both of these come installed on the computers you buy today. Select the browser that works best for you. In order to get a Web page or information site on the Internet you need to type in the Web address. Typing in the appropriate address is the quickest way to access a site. If you are planning on revisiting this site, add the site to your bookmarks or favorite sites. Bookmarks save time and typing mistakes by making a copy of the Web address in a pull down list.

However, many times you need to find a new Web site or resource information. Using search engines allows searching of the Internet for the desired materials. Search engines work by processing numerous information sources according to the keyword(s) or phases indicated by the user. Start with a wide search and narrow down the field to ensure that less information is missed. The use of "and," "or," "not" to tie words together assists in the narrowing down of the search. When the absolute phase or sentence is wanted use " " to indicate your desire. Some search engines use ${ }^{*},+$, or - to tie words together. Learn how the search engine operates to complete the best possible search. When using a search engine consider that the word Cow doesn't always mean a four-legged critter that eats hay. Often too vague or too specific words limited the results of a search. Take the time to try other words with similar meaning, you can find a gold mine of information. Don't be surprised by the sites that are listed from a search. Read the short description to make sure that you want to open the site. 
Some search engines useful in locating agricultural information are www.search.com; www.webcrawler.com; www.yahoo.com; www.google.com and www.dogpile.com. Learning how the search engine works permits for better retrieving of information. Find a search engine that you feel comfortable with and charge forward. Search engines vary in the amount of information they will find from their databases.

Once you find information that pertains to the subject matter, evaluate the Web site. Anyone can put information on the World Wide Web; so make sure the information is used appropriately. Rate Web sites by the information provided; author, date updated, affiliation and the type of information. Information that does not have these components may be useful but remember to use them cautiously. It may be someone's opinion and not research-based information.

Web address has several components that are needed to make them work. A typical Web address would be Http://sdces.sdstate.edu. Hypertext transmission protocol (HTTP) is the first component of the Web address. Next, you may see the www, which means World Wide Web. The component that we realize as the Web address or Universal Resource Locator (URL) is the name but actually URL is a series of numbers. However, URL that we use and see are words for ease and allows us to remember the name of the Web site. Within the URL, the top-level domain (various endings) seen on Web address gives some indication of the type of site. Typical ending are gov means government, org means organization, edu means education service, com means company and net means network. The top-level domain provides some guidance to the type of Web site.

A list of information obtained from the Internet would never end. What can ranchers get from the Internet; it can be used for watching the markets, finding equipment or services, keeping up on legislative bills and government policies, downloading of ranch/farm spreadsheets, breed association data, finding answers to questions and personal communications with experts. This list is only a few ideas on Internet use. The use of e-mail allows individuals to ask questions at their conveniences and the expert to reply. It minimizes the phone tag that occurs when both individual have differencing schedules. You can also write out more complex questions and avoid long distance charges.

Another use is chat rooms. They are like the local café. They are places where people carry on "real-time" conservation about things are interested in. There are several types of chat rooms, you can set one up with your friends or family using sponsored sites or download software from the Internet to set up your own session. You can also search the Internet for on-going chats on topics you are interested in. Also there is subject matter Web sites that will list on-going chats related to topics on the site. Within chat rooms, you can be a participant or an observer. If you want to join a sponsored chat room: 1) search the Internet for the topic you are looking for, 2) many chats require that you register and you will get a password and user id, and 3) real-time conversations. Remember statements are not always facts. Generally, they are someone's opinion on a subject. Chat rooms can be very informative and can be of interest to individuals. They can help you gauge the mood of people in the country and make you think and rationalize your position. 
Practicing safety on the Internet is extremely important. With all the information available on the Internet, you need to practice some safety precautions to ensure that your computer system is not harmed. Computer virus are real and a problem so remember to maintaining your anti virus software if you have it or get some. When downloading information take a few extra steps to ensure virus free information. Download the information to a temp file, and scan the document or information prior to opening. Once the information is found to be clean, then open the file and use the data. Close the pop-up window so that files are not being opened without your permission. Set-up your computer so you are asked each time before files are modified or your computer system is browsed. This allows you to determine if you want anything to change on your computer.

The Internet is an excellent information tool, which allows you to keep informed in the fast-paced livestock industry. Using common sense and observing a few safety precautions will keep your personal information and computer system safe.

Listed below are Web sites that are used to gather information by the authors.

\section{Market Information}

Chicago Mercantile Exchange - www.cme.com

Chicago Board of Trade - www.cbot.com

Minneapolis Grain Exchange - www.mgex.com

Kansas City Board of Trade - www.kcbt.com

Cattle Markets - www.panhandle.unl.edu/Personnel/Feuz/cattlemarkets.html

Livestock and Grain Market Report by City - www.ams.usda.gov/lsg/mncs/ls main.htm

\section{USDA and Federal Government Sites}

USDA Home Page - www.usda.gov

USDA Agricultural Marketing Service - www.ams.usda.gov

USDA Natural Resources Conservation Service Homepage - www.nrcs.usda.gov

USDA Agricultural Statistics - www.usda.gov/nass

USDA APHIS Veterinary Services - www.aphis.usda.gov

National Animal Health Monitoring System (NAHMS) - www.aphis.usda.gov/vs/ceah/cahm

United States Department of Health and Human Services - www.hhs.gov 
Environmental Protection Agency - www.epa.gov

\section{General Listing of Other Sites}

Animal-Related Websites - netvet.wustl.edu

Oklahoma State University Livestock Library - www.ansi.okstate.edu/library

Kansas State University Livestock Library - www.oznet.ksu.edu/library/lvstk2

Breed Cattle Resources - www.ansi.okstate.edu/library/cattbeef.html

Cooperative Extension Services by state - www.ansi.okstate.edu/internet/Agexten.html

Colorado Extension Service - www.ext.colostate.edu

Nebraska Extension Service - www.ianr.unl.edu

South Dakota Extension Service - sdces.sdstate.edu

Wyoming Extension Service - www.uwyo.edu/ces/ceshome.htm

Extension Publications:

Colorado - www.cerc.colostate.edu

Nebraska - www.ianr.unl.edu/pubs/Beef/

South Dakota - www.abs.sdstate.edu/ars/beefext/pubs.htm

Wyoming - www.uwyo.edu/ces/pubs.htm

North Dakota - www.ag.ndsu.nodak.edu/livestock.htm

\section{Specific Websites}

Temple Grandin - www.grandin.com

SDSU Crop and Livestock Budgets - www.abs.sdstate.edu/ag_econ/budgets.htm

Research Institute on Livestock Pricing (includes articles by Wayne Purcell) www.aaec.vt.edu/rilp/index.html

The Market Advisor (Harlen Hughes, NDSU) - www.ag.ndsu.nodak.edu/cow

Alternative feeds for Ruminants (NDSU) -

www.ext.nodak.edu/extpubs/ansci/livestoc/as1182.htm

Managing for Today's Cattle Market and Beyond -

ag.arizona.edu/AREC/WEMC/TodaysCattlePub.html

National Cattlemen's Beef Association - www.beef.org 
State Cattlemen's Associations

Colorado - cca.beef.org

Nebraska - www.nebraskacattlemen.org

South Dakota - www.sdcattlemen.org

Wyoming - could not find Web site

Agweb - www.agweb.com

Cattle Fax - www.cattle-fax.com

Chatrooms: - www.ranchers.net; $\underline{\text { www.agriculture.com }}$

Ask A Specialist - beef.unl.edu

Breeds of Livestock - www.ansi.okstate.edu/breeds

$\underline{\text { R-CALF - www.rcalf.com }}$ 